\title{
AREAS WITH HIGH FLORISTIC DIVERSITY IN SĂLAJ COUNTY THAT REQUIRE PROTECTION AND CONSERVATION
}

\author{
Paul-Marian SZATMARI ${ }^{1,2}$, Gavril NEGREAN ${ }^{3}$, Carol KARÁCSONYI ${ }^{4}$ \\ ${ }^{1}$ Biological Research Center, Botanical Garden "Vasile Fati" Jibou \\ 16 Wesselényi Miklós St., RO-455200 Jibou, Romania \\ ${ }^{2}$ Babeș-Bolyai University, 42 Republicii St., RO-400015 Cluj-Napoca, Romania \\ ${ }^{3} 55$ Iuliu Maniu Bd., RO-77531 Bucureşti, Romania \\ ${ }^{4}$ Allgäustr.2, D-88212 Ravensburg, Germany \\ e-mail: paul_marian87s@yahoo.com
}

\begin{abstract}
Following floristic studies undertaken over several years throughout Sălaj County, we have identified many regions of exceptional floristic diversity. Here, the habitats are less affected by human activity, revealing an overview of the vegetation that once dominated the county. These sites conserve a number of rare, protected, endemic, steppe relict or otherwise interesting plant species from a scientific and floristic point of view. These areas include forests, marshes, rocky places with limestone or gypsum, and the meadow-steppe characteristic for Transylvania.

The establishment of new protected zones to include these areas of vegetation is therefore extremely important to ensure the perpetuation of the rare species, some of which have large populations. Many of these species reach their northern limit in Romania or are reported for the first time in the north-western part of the country. The proposals for protected areas come as a result of a detailed scientific research on the county. These studies will complete the knowledge of the flora of Sălaj County, which is poorly documented, and because of this the region has a very small number of protected areas.
\end{abstract}

Keywords: Sălaj County flora, protected areas, rare and protected species.

\section{Introduction}

Sălaj County is among the least studied regions in Romania in terms of flora and fauna, being considered a 'blank spot' on the map of Transylvania. As a consequence, it was necessary to start as soon as possible studies on the flora and fauna of the region, which are being conducted by specialized researchers in almost all groups of living organisms. The research in question was necessary because many species of plants were misplaced in the flora lists of the Agency for Environmental Protection Sălaj from older works [3, 17, 13], species that are mentioned in the standard sheets of Natura 2000 sites (such as Hepatica transsilvanica or Betula nana), outlier species from the Balkans which have their northern limit in the Danube Gorge (Campanula crassipes [10]) or alpine and subalpine species, when in Sălaj County the maximum altitude is just 996 m in Măgura Priei from Meseș Mountains, dominated by beech forests. The same Environmental Protection Agency cites for Sălaj County only 287 species of vascular plants; in reality their number reaches more than 2000 species. In the Prisnel Peak region alone are cited 560 species [12], and the spontaneous flora of the botanic garden in Jibou, with 27 ha, exceeds 650 species [22]. Also, the Environmental Protection Agencies from Cluj and Sălaj counties mention only 6 Species of Community Interest, among which Arctostaphylos uva-ursi has not been found, and certainly is not growing in the Sălaj region. Abrudan and Medve [5] 
specified that the number is very small compared to the neighbouring counties in the north-west, which together have 31 taxa under protection. Also, in the absence of previous studies, in Sălaj region only 14 types of habitat were found [3], while in all the north-western counties in Romania this number reaches 85 .

Since the mid-20th century, by the Decision no. 259 of 29 July 1975 the Executive Committee of the People's Council from Sălaj County designated four plant species that should be protected "wherever they are", namely: yew (Taxus baccata?), butcher`s broom (Ruscus aculeatus $^{\text {? }}$ ), Lady's-slipper orchid (Cypripedium calceolus) and Turkish hazel (Corylus colurna?) $[1,5]$. By the Decision no. 5 of 28 July 1995, the Council of Sălaj County expanded the protected list of plant species to include 32 plants, and Turkish hazel was removed from the list [2]. The 29 new species added to the list of protected plants were two daffodils [Narcissus angustifolius and N. stellaris (actually the same species)], Fritillaria meleagris, Larix decidua?, Leontopodium alpinum?, Gentiana lutea?, Nigritella nigra? and N. rubra?, Angelica archangelica?, Daphne blagayana? and D. cneorum, Arctostaphylos uva-ursi?, Linaria alpina?, Gypsophila paniculata?, Hyoscyamus niger, Iris graminea, Romanian peony (Paeonia sp.?), Festuca valesiaca!, Festuca rupicola!, Carex humilis, Valeriana officinalis!, Plantago argentea, Polygala major, Adonis vernalis and A. volgensis?, Salvia transsilvanica, Potentilla anserina!, Sorbus aucuparia and Nepeta cataria! [5]. On the county's "Red List 2004", at the Environmental Protection Agency Sălaj were listed 20 species of the only 287 species of higher plants believed to be in the county: 3 species of peat moss (Sphagnum spp.), 3 species of conifers (Taxus baccata?, Abies alba?, Larix decidua?), 9 species of dicotyledonous plants (Daphne blagayana?, Daphne mezereum, Angelica archangelica?, Drosera rotundifolia, Castanea sativa, Arctostaphylos uva-ursi?, Calluna vulgaris, Gentiana lutea?, Salvia transsilvanica) and 5 species of monocots (Fritillaria meleagris, Narcissus stellaris, Nigritella? (2 species) and Cypripedium calceolus (Annex II) [5, 3]. Most of these species are mentioned incorrectly in the county`s flora [indicated by a question mark (?)], errors due to the lack of field studies and botanists. Other species are particularly common across the county and do not require protection and preservation, in many cases they are even ruderal weeds or introduced trees such as European larch and chestnut [marked with an exclamation mark (!)]. Thus the research in recent years also seeks to clarify the irregularities mentioned so far, in order to obtain lists of species that really do need protection.

Until now, in Sălaj County there are six Natura 2000 sites, many of them very poorly studied regarding their flora (ROSCI0192 Peştera Măgurici, ROSCI0209 Racâş-Hida, ROSCI0257 Tusa - Barcău, ROSCI0314 Lozna, ROSCI0322 Muntele Șes, ROSPA0114 Cursul mijlociu al Someșului) and 12 other small-sized protected areas, especially for nature landscapes (Grădina Zmeilor, Pietrele Moşu şi Baba, Calcarele de Rona, Balta Cehei, Rezervaţia peisagistică Stanii Cliţului, Gresiile de pe Stânca Dracului, Mlaştina de la Iaz, Pădurea La Castani, Stejărişul Panic, Stejărişul de baltă Panic, Lunca cu lalea pestriţă - Valea Sălajului, Pădurea Lapiş) [25]. Therefore, this paper proposes a number of new areas that require protection, these being some of the richest sites for biodiversity, not only in Sălaj, but also in Transylvania, with many rare and protected species reported here for the first time. The data collected in the field are being processed, which is why we cannot discuss all the areas proposed for protection in this work, and they will appear in a forthcoming paper. 


\section{Materials and Methods}

The detailed research of these areas took place over several years (2012, 2013, 2014, $2015,2016,2017)$ investigating the vegetation over all the four seasons. The plant species were observed in the field and the unknown individuals were collected and determined. They were identified according to the Romanian taxonomic keys: Săvulescu (ed.), 1952-1976 [19]; Ciocârlan, 2009 [7]; Sârbu et al., 2013 [20]. Most species were gathered and pressed, and the herbarium specimens were submitted to various institutions (Carei, Cluj, Jibou, Bucharest, Galati, Iasi, Budapest etc.). Their nomenclature followed the APG III classification system according to The Plant List, Euro + Med Plantbase and Catalogue of Life sites [24, 4, 18].

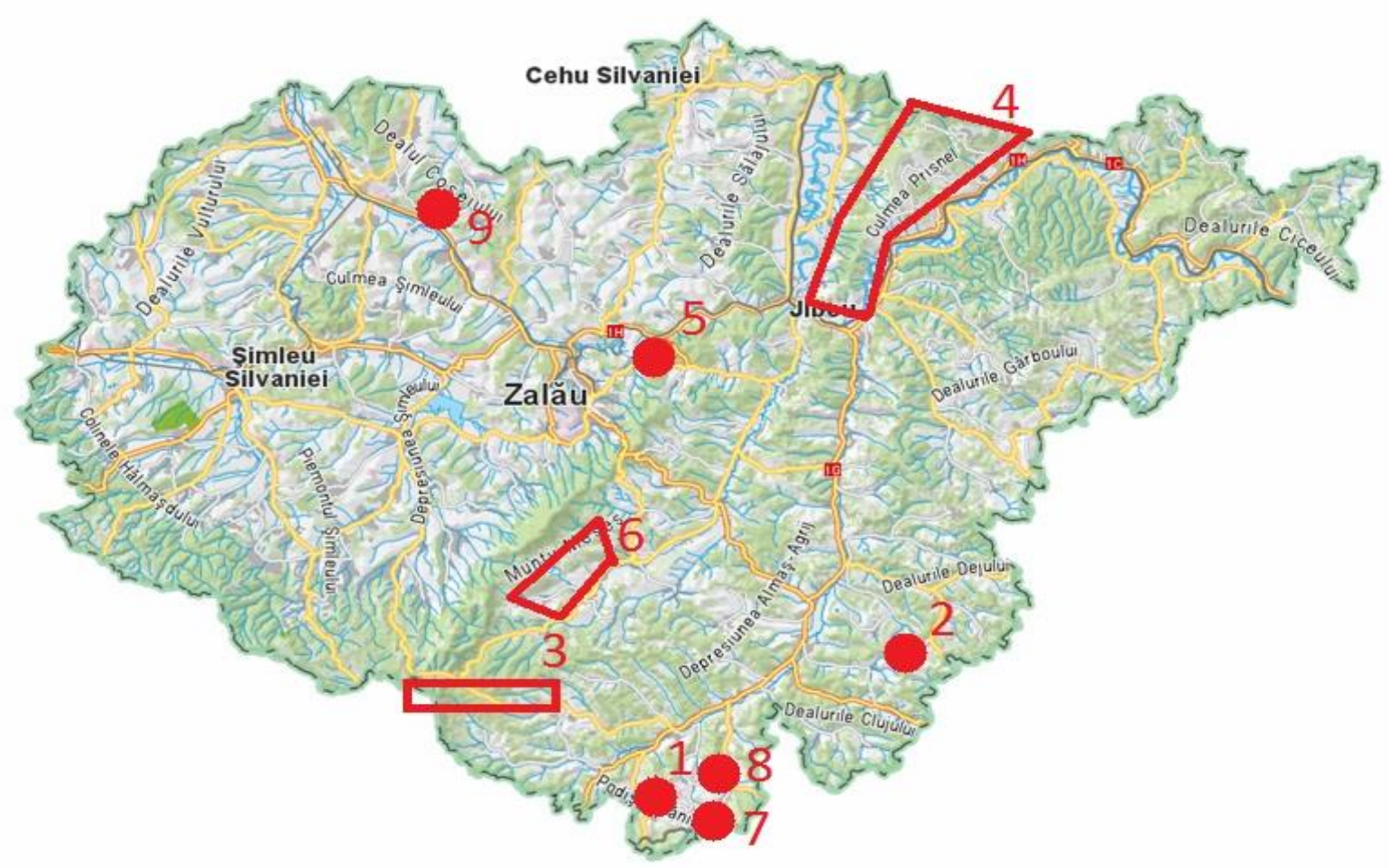

Fig. 1: The proposed floristic reservations for Sălaj County: 1. The gypsum from Sfăraş-Jebucu; 2. The hillsides with steppe vegetation from Ugruţiu; 3. The Poicului Valley from Meseş Mountains; 4. Prisnel Ridge; 5. Puguior Hill in the Ortelec Valley; 6. The limestones from Buciumi-Sângeorgiu de Meseş; 7. The Riseg Hill near Stana; 8. The hills between Petrindu and Petrinzel; 9. The hills from Sălăjeni.

The proposals for protected areas presented in this paper have followed some important criteria:

- the presence of a high number of rare, protected and endemic plant species, with large and viable populations;

- the presence of endangered habitats and plant associations or with a high biodiversity;

- these areas are mostly natural or semi-natural, and less affected by human activities;

- these habitats also include numerous rare invertebrates and vertebrates at their northern limit, many being endangered species;

- the presence of numerous landscape, geological, paleontological and speleological elements with major scientific, ecological and cultural importance. 
The rare and protected species from the Red Lists are in the following publications: Dihoru \& Negrean, 2009 [9]; Boşcaiu et al., 1994 [6]; Dihoru \& Dihoru, 1994 [8]; Negrean, 2001 [14]; Negrean \& Oltean, 1989 [15]; Oltean et al., 1994 [16]. The Natura 2000 priority habitats were interpreted according to the Interpretation Manual of Natura 2000 habitats in Romania [11].

\section{Results and Discussion}

According to the above criteria, the following nine areas with remarkable floristic richness have been chosen for protection (Fig.1).

\section{The gypsum from Sfăraş-Jebucu (Gipsurile de la Sfăraș-Jebucu)}

This area is by far the richest floristic region of Sălaj and most likely one of the most important ,hot-spots' in Transylvania and Romania. The floristic richness is due to the substrate which consists of gypsum and limestone, with a specific flora adapted to these habitats [21]. At the same time, the natural landscape is largely unchanged since ancient times, this being the reason why this region preserves the archaic flora that once dominated the former open unforested areas in the Transylvanian Basin. It is also a refuge for a number of endemic and rare species, some nearly extinct in the flora of Romania.

The region is dominated by high hills, consisting entirely of gypsum rock which forms white patches on the surface. The soil, a rendzic leptosol, is thin and poor in organic matter, and strongly basic. The landscape is often unstable, with easily crumbling rocks, which makes growth difficult for many species in the area, other than those adapted to these conditions (the gypsum flora). Such protected areas are also found close by in Cluj County - the gypsum from Leghia, but unfortunately other gypsum areas in Cluj are in an advanced state of decay, most species being affected by human activities. In past years the site from Sfăraș-Jebucu has been affected by overgrazing and frequent passing flocks of sheep, some hillsides being washed away during heavy rains due to the disappearance of vegetation cover.

The vegetation is typical for the thermophilic limestone and Transylvanian steppe areas dominated by xerophile, xero-mesophile, subthermophile and thermophilic species, mostly adapted to open areas, species that cannot withstand shading. On a surface of just $2 \mathrm{~m}^{2}$, up to 20 species can be counted, which is remarkable.

The area proposed for protection, called "Pad" by the locals, is situated between the villages of Sfăraş and Jebucu, on the left side of the road that connects them, starting from Sfăraș. The limit of the gypsum hills ends on the plateau occupied by agricultural crops. It is noteworthy that these hills form a continuous strip, with no agricultural land between them, which will facilitate the delimitation of the protected area.

Due to the lack of space in the present work, we will mention only the most important species. Among these are the endemic species, primarily classified into two categories:

- Transylvanian endemic species: Cephalaria radiata, Onosma pseudoarenaria, Jurinea transylvanica.

- Carpathian endemic species: Sesleria heufleriana, Viola jooi, Thymus comosus.

Species included in the Red Book of Romania [9] are Onosma pseudoarenaria and Gypsophila collina. Gypsophila collina (Fig.2B) is probably one of the most important plants, 
because of its rarity. Present only at 7-8 scattered points in Cluj and Sibiu counties, it occurs only in Romania, Moldova and Crimea [9, 4].

From the national Red Lists have been identified many species, some extremely rare in the county: Daphne cneorum, Echinops ritro subsp. ruthenicus, Dictamnus albus, Klasea radiata, Seseli elatum subsp. osseum, Jurinea transylvanica, Rhinanthus wagneri, Seseli gracile, Cirsium furiens. Other rare and important plants for the region: Artemisia alba (Fig.2A) (the species is here at the northern limit of its area in Romania, being reported in a few locations in the country), Astragalus monspessulanus, Linum flavum, Linum hirsutum, Linum tenuifolium, Linum austriacum, Astragalus austriacus, Astragalus onobrychis, Allium denudatum, Alcea pallida, Cirsium pannonicum, Stipa capillata, Stipa pulcherrima, Stipa pennata, Epipactis atrorubens, Clematis integrifolia, Scorzonera austriaca, Euphorbia glareosa, Salvia nutans, Scorzonera purpurea, Leontodon crispus, Pulsatilla montana subsp. dacica, Centaurea indurata, Asyneuma canescens, Nonea pulla, Teucrium montanum, Helianthemum canum, Helianthemum nummularium subsp. obscurum, Centaurea apiculata subsp. spinulosa, Rhamnus saxatilis subsp. tinctoria, Orobanche alba, Allium flavum, Plantago argentea, Chamaecytisus albus, Anthericum ramosum, Adonis vernalis, Carex humilis, Festuca pallens, Campanula sibirica, Polygala major, Prunella grandiflora, Cleistogenes serotina, Anagallis foemina, Bromus squarrosus, Euphorbia seguieriana, Alyssum desertorum, Artemisia campestris, Aster amellus, Astragalus cicer, Bupleurum falcatum, Erysimum odoratum, Helianthemum nummularium subsp. obscurum ,var. Albiflorum", Inula ensifolia, Onobrychis arenaria, Orobanche lutea, Phleum montanum, Seseli annuum, Thesium linophyllon, Achillea pannonica, Aconitum anthora, Campanula bononiensis, Thalictrum minus, Dianthus giganteiformis subsp. pontederae, Stipa dasyphylla, Stipa tirsa, Odontites lutea, Rosa micrantha, Epilobium dodonaei, Sisymbrium strictissimum and Sonchus palustris (in the wet valley), etc.

The flora of Sfăraş-Jebucu has drawn the attention of the Biological Research Centre in Jibou (Sălaj County), that carries out genetic studies using molecular markers in order to create a database and to clarify the taxonomic position of some taxa not studied until now.

Among the identified Natura 2000 habitats we observed: 6190 Rupicolous Pannonic grasslands (Stipo-Festucetalia pallentis); 6240* Sub-pannonic steppic grasslands; 62C0* PontoSarmatic steppes.
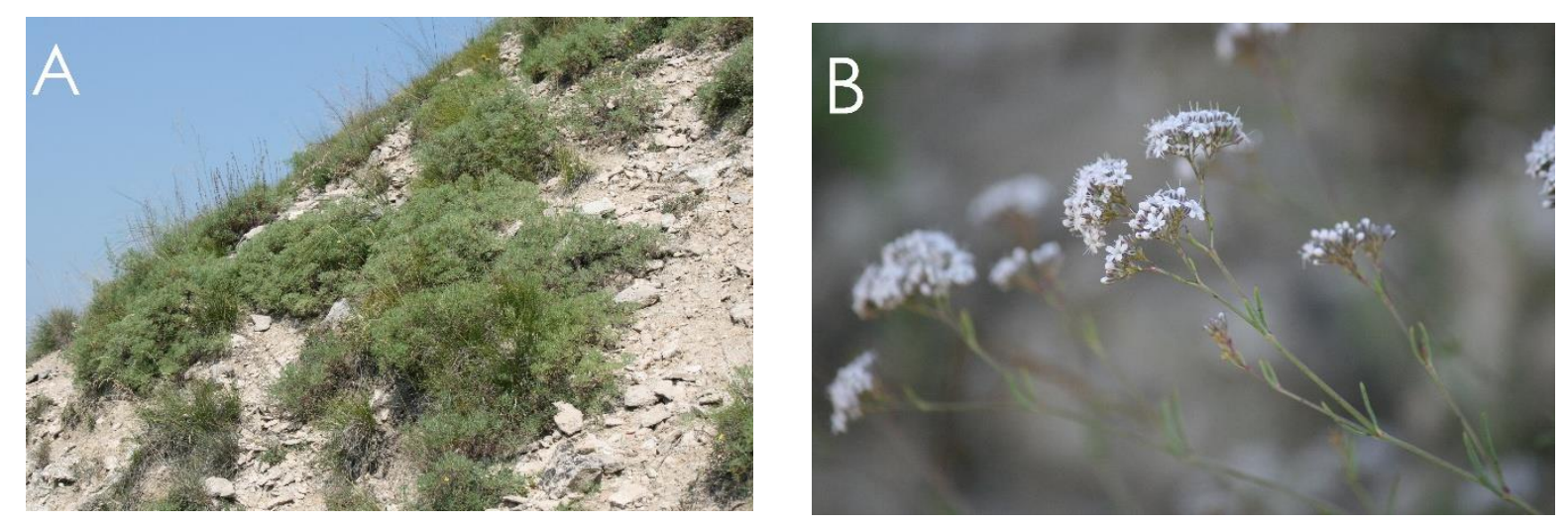

Fig. 2: A. Artemisia alba and B. Gypsophila collina growing on the gypsum from Sfăraș-Jebucu 
2. The hillsides with steppe vegetation from Ugruţiu (Coastele cu vegetație stepică de la Ugruțiu)

Located on the border with Cluj County, this region most resembles the so-called Transylvanian steppes of central Transylvania, many species of steppic origin having their northern boundary on the respective hillsides. It is also an area less affected by human activities, but in recent years we have found more traces of passing flocks of sheep, which can endanger the archaic flora that exists only here.

The substrate is also made by limestone, with gypsum patches on the surface, but the soils are more consistent. The average altitude exceeds $300 \mathrm{~m}$. The vegetation is also adapted to aridity, even better than that of the Sfăraş-Jebucu area, most of the species being xerophile, xeromesophile, thermophilic and subtermophile.

The area proposed for protection occupies the southern steep hillsides bordering the Ugruţiu Valley between the localities Ugruţiu and Hida. The characteristic vegetation ends on the top of the hills at the border with forests of Turkey oak (Quercus cerris), which grow on the opposite slopes. Although the area is surrounded by thermophilic woods, the herbaceous steppic vegetation is not likely to be secondary following logging, but rather it coexists with these forests since ancient times on the gypsum formations.

The main dominant plants are: Festuca rupicola, Festuca valesiaca, Bothriochloa ischaemum, Brachypodium pinnatum and Stipa pennata.

By far the most important plant is a very rare orchid species for Romania, which has here its northern distribution limit - Ophrys apifera, a species listed in the Red Book of Romania and protected in all the countries in the region. Its presence here confirms that the species exists in Transylvania [23].

Other important Red-listed species are: Anacamptis morio, Adonis vernalis, Allium denudatum, Astragalus austriacus, Astragalus monspessulanus, Astragalus onobrychis, Cleistogenes serotina, Jurinea transylvanica, Jurinea mollis, Linum flavum, Linum tenuifolium, Onosma pseudoarenaria, Plantago argentea, Pulsatilla montana subsp. dacica, Salvia nutans, Klasea radiata, Seseli pallasii, Stipa pennata, Stipa capillata, Stipa tirsa, Anacamptis coriophora subsp. fragrans, Cephalaria radiata, Carex humilis, Dictamnus albus, etc. Some remarkable species are found only in the Ugruţiu area in Sălaj County or on the neighbouring hills at maximum distance of $10 \mathrm{~km}$ (Salvia transsilvanica, Ajuga laxmannii, Carduus hamulosus, Oxytropis pilosa, Phlomoides tuberosa, Allium fuscum).

Natura 2000 habitats identified here: 6210 Semi-natural dry grasslands and scrubland facies on calcareous substrates (Festuco-Brometea) (*important orchid sites); 6240* Subpannonic steppic grasslands; 62C0* Ponto-Sarmatic steppes.

\section{The Poicului Valley from Meseş Mountains (Valea Poicului din Munții Meseș)}

This is probably one of the richest sites with tall hygrophile growing communities in the Sălaj region and adjacent areas (Fig.3C). This valley requires urgent protection, as the wetlands in the north-west are shrinking from year to year due to anthropogenic impact. At the same time, this valley is only slightly affected due to its isolation, the flora containing many rare and relict plants, even some mountain species at a much lower altitude than usual.

The main source of water is the Poic creek that feeds the adjacent marshes. On its sides stretch alder floodplains and meadows of tall hygrophilic plants with a remarkable biodiversity. 
The mesophilic adjacent vegetation is also remarkable.

The area proposed for protection extends along the Poicului Valley from the village of Mesteacănu to Poicu hamlet, on the edge of Sălaj County, but the protected area should include the part that continues towards Cluj County.

Nationally Red-listed species are: Salix aurita, Trollius europaeus, Epipactis palustris, Dactylorhiza cordigera, Carex diandra, Carex appropinquata, Iris sibirica and Gladiolus imbricatus.

The alder (Alnus glutinosa) floodplains contain numerous woody species of mountain origin: Salix aurita, Salix purpurea, Prunus padus, Sambucus racemosa. The hygrophilic vegetation of thickets, alders and open areas is dominated by Carex species, such as: Carex elata, Carex acuta, Carex acutiformis, Carex riparia, Carex brizoides, Carex nigra, Carex lepidocarpa. From the Red-listed species can be mentioned: Carex appropinquata, Carex elongata and Carex diandra. These species are listed as glacial relicts in Romania. Eriophorum angustifolium and other grass species are dominant in the meadows (Deschampsia cespitosa, Molinia caerulea, Poa palustris, Poa trivialis, etc.). The vegetation in the alder forests is formed by: Caltha palustris, Cardamine amara, Stellaria nemorum, Athyrium filix-femina, Dryopteris carthusiana etc. Other important species: Geranium palustre, Parnassia palustris, Cirsium palustre, Veratrum album, Cirsium rivulare, Polygonum (Persicaria) bistorta, Filipendula ulmaria subsp. denudata, Oenanthe silaifolia, Angelica sylvestris, Thalictrum lucidum, Sanguisorba officinalis, Veronica longifolia, Lathyrus hallersteinii, Galium uliginosum, Peucedanum palustre, Crepis paludosa, Ornithogalum pyrenaicum, etc. The mesophilic vegetation at the marsh edges contains other remarkable species: Silene heuffelii, Dianthus deltoides, Hieracium aurantiacum, Campanula cervicaria, Calluna vulgaris, etc.

Natura 2000 habitats identified here: $\mathbf{6 4 1 0}$ Molinia meadows on calcareous, peaty or clayey silt-laden soils (Molinion caeruleae); $\mathbf{6 4 3 0}$ Hydrophilous tall-herb fringe communities of plains and of the montane to alpine levels; 91E0* Alluvial forests with Alnus glutinosa; Fraxinus excelsior (Alno-Padion, Alnion incanae, Salicion albae).
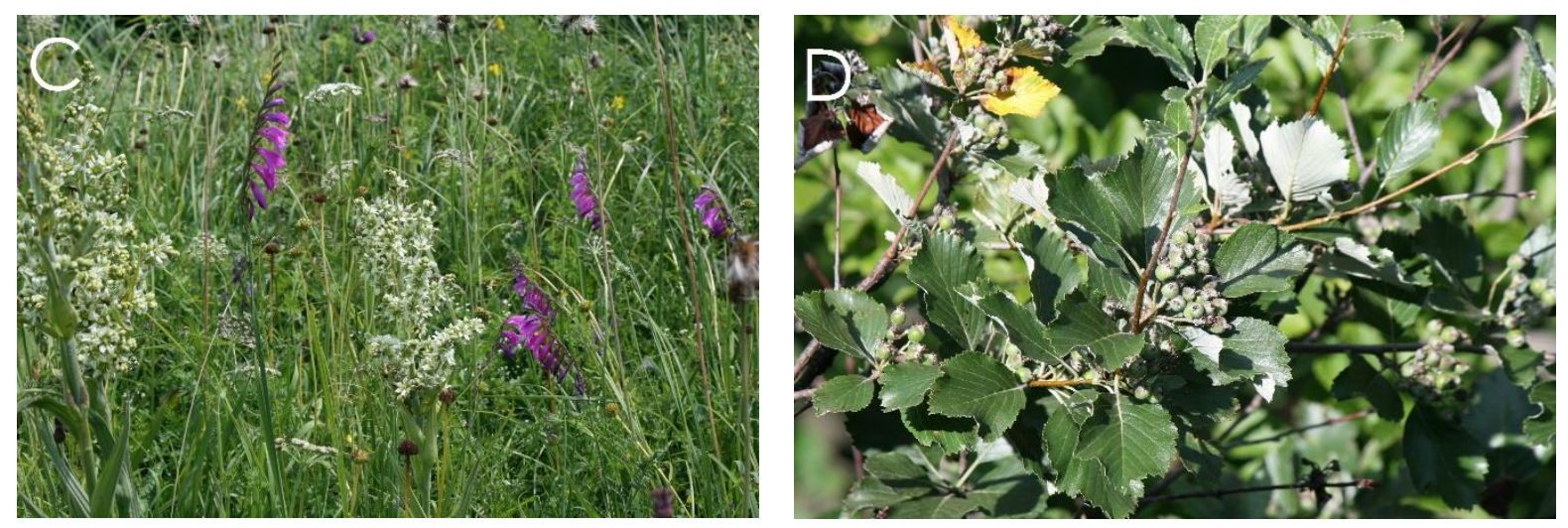

Fig. 3: C. Hygrophilous vegetation in Poicului Valley. D. Sorbus danubialis on the cliffs of Cozla Plateau (Prisnel Ridge).

\section{Prisnel Ridge (Culmea Prisnelului)}

The area proposed for protection includes all the hills under the general name of Prisnel Ridge that extends from the northern border with Maramureș County (Prisnel Peak near the 
village of Vălişoara) to Rona Hill in the south (or Rákóczi Hill) near Jibou. The landscape is dominated by high hills, steep valleys and plateaux covered with forests and extensive meadows. The inaccessible areas have facilitated the survival of many rare and remarkable species. The most important areas studied are the two limits of the ridge (Prisnel Peak, Cozla Plateau and Rákóczi Hill).

The substrate consists entirely of limestone, which, especially in areas with steep slopes, cliffs and screes, retains a specific thermophilic vegetation. The area is also a bridge for the Carpathian and limestone species from Meseş Mountains (Apuseni Mountains) from the south to the northern part of the Eastern Carpathians, or vice versa.

In the northern part, the beech forests are dominant, notably the remarkable archaic beech forest that covers the Prisnel Peak and passes into Maramureș County. The strip of moist forest with a unique vegetation is composed by species of Acer.

Among the important species, we have noticed the Carpathian endemics: Aconitum moldavicum, Silene nutans subsp. dubia, Symphytum cordatum, Cardamine glanduligera, Crocus banaticus, Sesleria heufleriana, Scabiosa columbaria subsp. banatica, Viola jooi, Thymus comosus and Helleborus purpurascens. Sorbus danubialis (Fig.3D), at the northern limit of its distribution area, was identified on the slopes of Cozla Plateau.

Other remarkable or rare species, from the Red Lists, are: Elymus hispidus subsp. barbulatus, Sedum album, Galium abaujense, Iris pumila (at the northern limit of its distribution), Iris graminea, Centaurea rocheliana, Melampyrum barbatum, Gentianopsis ciliata, Galium pumilum, Neottia nidus-avis, Cephalanthera damasonium, Melittis melisophyllum, Atropa belladonna, Gentiana cruciata, Ornithogalum pyramidale, Anthericum ramosum, Linum flavum, Linum tenuifolium, Seseli libanotis, Rosa tomentosa, Asplenium scolopendrium, Lunaria rediviva, Staphylea pinnata, Helictotrichon compressum, Asperula tinctoria, Anemone sylvestris, Ferulago sylvatica, Reseda luteola, Orobanche elatior, Rosa micrantha, Rhinanthus wagneri, Piptatherum virescens, Platanthera bifolia, Epipactis helleborine, Euphorbia epythimoides, Silene heuffelii, Oenanthe banatica, etc. Aquilegia vulgaris, of which the origin is still uncertain, is found among screes under Prisnel Peak.

Natura 2000 habitats identified here: 6190 Rupicolous Pannonic grasslands (StipoFestucetalia pallentis); $\mathbf{6 5 1 0}$ Lowland hay meadows (Alopecurus pratensis, Sanguisorba officinalis); 9180* Tilio-Acerion forests of slopes, screes and ravines; 91V0 Dacian Beech forests (Symphyto-Fagion).

\section{Puguior Hill in the Ortelec Valley (Dealul Puguior din Valea Ortelec)}

Puguior Hill is located near Zalău town, outside the village of Ortelec, facing Măgura Moigradului (a volcanic plug). The area includes xerophile meadows situated on very rugged limestone bedrock and a downy oak forest (Quercus pubescens). This forest, most likely unique in north-western Romania, is formed exclusively by thermophilic woody species - downy oak (Quercus pubescens) and, rarely, Hungarian oak (Quercus frainetto), found here at the northern limits of their range. 

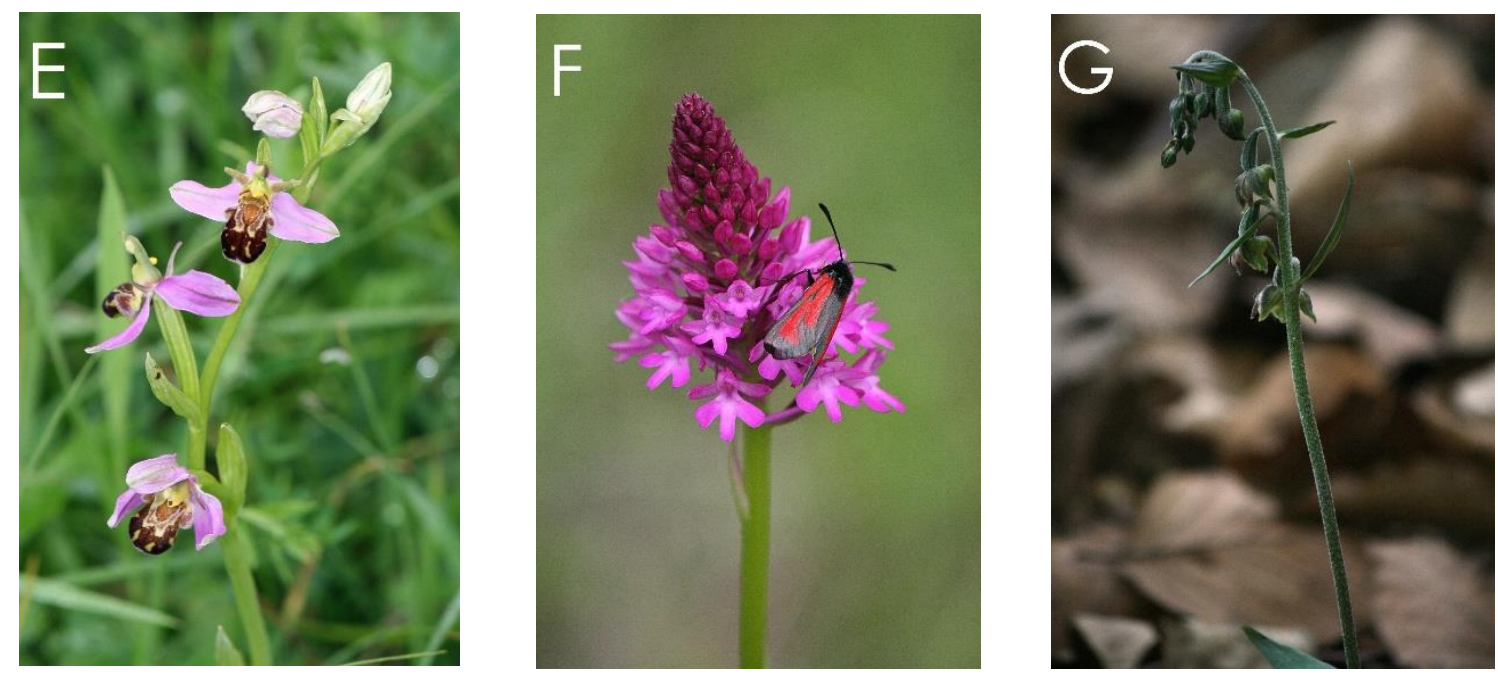

Fig. 4: Some of the orchids growing on Puguior Hill: A. Ophrys apifera. B. Anacamptis pyramidalis. C. Epipactis microphylla.

The vegetation is also rather typical for a subthermophile climate, many species being Steppic or Mediterranean in affinity.

Red-listed species are: Myosotis discolor and Ophrys apifera (Fig.4E) (both mentioned in the Red Book of Romania), Anacamptis pyramidalis (Fig.4F), Orchis militaris, Neotinea ustulata, Epipactis microphylla (Fig.4G), Cephalanthera longifolia, Cephalanthera damasonium, Neottia nidus-avis and Dictamnus albus. It is worth mentioning the Carpathian endemic Silene nutans subsp. dubia, and the Transylvanian Cephalaria radiata. A number of rare, steppic and remarkable species for Sălaj County complete the vegetation: Viola mirabilis, Muscari botryoides, Salvia austriaca, Odontites lutea, Clematis recta, Pulsatilla montana subsp. dacica, Alyssum repens subsp. transsilvanicum, Linum tenuifolium, Linum flavum, Allium lusitanicum, Anchusa barrelieri, Polygala major, Anthyllis vulneraria subsp. polyphylla, Melampyrum barbatum, Euphorbia epythimoides, etc.

Natura 2000 habitats identified here: 6240* Sub-pannonic steppic grasslands; 91H0* Pannonian woods with Quercus pubescens.

6. The limestones from Buciumi-Sângeorgiu de Meseş (Calcarele de la Buciumi Sângeorgiu de Meseș)

The proposed area occupies a quite significant surface, which includes the main part of the limestone in the perimeter of Buciumi village, focusing mostly on the Sângeorgiu de Meseş area. It is probably one of the places in the county where most of the limestone is at the surface. This facilitated the development and survival of typical vegetation. In addition to the flora, the area is characterized by numerous fossils found just below the surface and the presence of a very wild landscape. The site is important because the presence of a large number of limestone-loving species that have migrated northward from the Apuseni Mountains.

The species listed on the national Red Lists are: Waldsteinia geoides, Dictamnus albus, Bupleurum rotundifolium, Cotoneaster niger, Epipactis helleborine. Carpathian endemics are: Silene nutans subsp. dubia, Viola jooi, Thymus comosus, Helleborus purpurascens. Other remarkable species: Cephalaria radiata Helianthemum canum, Linum tenuifolium, Linum 
flavum, Linum austriacum, Adonis aestivalis, Alyssum repens subsp. transsilvanicum, Rhamnus saxatilis subsp. tinctoria, Galeopsis angustifolia, Carex depressa subsp. transsilvanica, Teucrium montanum, Thymelaea passerina, etc.

Natura 2000 habitats identified here: 6190 Rupicolous Pannonic grasslands (StipoFestucetalia pallentis).

\section{The Riseg Hill near Stana (Dealul Riseg de lângă Stana)}

Situated at the border with Cluj County, Riseg Hill is a particularly important refuge for rare plants and for those characteristic of the limestone areas in Transylvania. Here we encountered species that are no longer found north of these areas.

The grass vegetation is generally of steppic origin, preserved especially on the hilltop. The slopes are dominated by pure or mixed beech forests with a rich vernal flora. Specimens of Juniperus communis and Larix decidua are most likely to derive from ancient groves of anthropogenic origin. Unfortunately, the site is subjected to frequent burning of vegetation by the local shepherds. These fires are the main reason why the endangered species Daphne cneorum has almost disappeared from the hillside to Cluj County.

The species included in the national Red Lists are: Daphne cneorum (Fig.5H) (widespread here; also, this is one of the two sites where it grows in Sălaj County), Seseli gracile, Iris aphylla (Natura 2000 priority species), Klasea radiata, Neotinea ustulata, Neotinea tridentata, Dactylorhiza sambucina, Anacamptis morio, Orchis militaris. Other rare and remarkable species are: Adonis vernalis, Pulsatilla montana subsp. dacica, Scorzonera austriaca, Scorzonera hispanica, Scorzonera purpurea, Aconitum anthora, Ferulago sylvatica, Cleistogenes serotina, Trinia glauca, Asyneuma canescens, Astragalus monspessulanus, Mercurialis ovata, Anemone sylvestris, Hierochloe repens, Plantago argentea, Tephroseris integrifolia, Cotoneaster pyrenaicus, Rosa spinosissima, Geranium sanguineum, Helianthemum canum, Euphorbia angulata. Transylvanian endemic species are: Centaurea pugioniformis, Cephalaria radiata, Jurinea transylvanica.

Another interesting category of plants are the mountain elements that survived here, having a relict character, such as: Helleborus purpurascens, Ranunculus oreophilus, Valeriana walhrothii, Polygala amara, Phyteuma orbiculare, Minuartia verna and Tephroseris papposa. Some of them are Carpathian endemic species: Sesleria heufleriana, Helictotrichon decorum, Viola jooi.

Natura 2000 habitats: 6240* Sub-pannonic steppic grasslands.

\section{The hills between Petrindu and Petrinzel (Dealurile dintre Petrindu și Petrinzel)}

The hills are on the right side of the country road that connects the two villages. The vegetation is dominated by xerophile, xero-mesophile and subthermophile species. In some places spots of gypsum appear at the surface with a specific vegetation.

The need to preserve these grasslands is due to the fact that the species Adonis vernalis is widespread on these hills. In spring, the hills are covered entirely by a carpet of the large yellow flowers (Fig.5I). Other rare and remarkable species are: Chrysopogon gryllus, Orobanche elatior, Viola collina, Linum hirsutum, Cleistogenes serotina, Thymelaea passerina, etc.

Natura 2000 habitats identified here: 6240* Sub-pannonic steppic grasslands. 

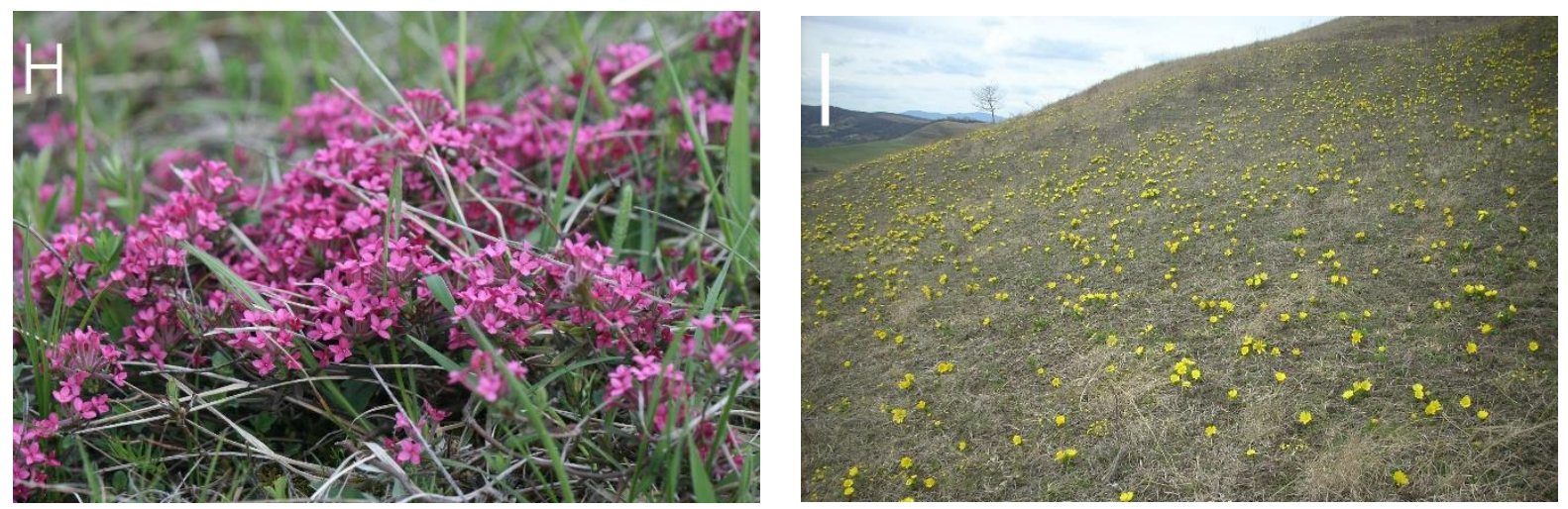

Fig. 5: H. Daphne cneorum on the plateau of Riseg Hill. I. The hills between Petrindu and Petrinzel are covered by the yellow flowers of Adonis vernalis in spring.

\section{The hills from Sălăjeni (Dealurile de la Sălăjeni)}

Located on the left side of the road Tășnad-Zalău, these high hills are a major factor that facilitates the spread of continental species to the west (Tăşnad Hills, Pannonian Plain). Although the substrate is not limestone, the vegetation is luxuriant, with a large number of species. On these hills was described a Rosa taxon new for science: Rosa pocsii var. karacsonyii.

Red-listed species are: Elymus hispidus subsp. barbulatus, Bupleurum rotundifolium, Rhinanthus wagneri. Other rare and remarkable species: Linum hirsutum, Linum flavum, Onobrychis arenaria, Crataegus rhypidophylla, Artemisia pontica, Althaea cannabina, Carthamus lanatus, Allium flavum, Allium rotundum, Ornithogalum pyramidale, Chamaecytisus albus, Nigella arvensis, Rosa gallica, Rosa jundzilii, Thymelaea passerina, Rosa zagrabiensis, etc.

\section{Conclusions}

Being one of the least studied counties regarding its flora, Sălaj conceals countless surprises. The region has a very rich flora that is mainly due to the huge areas of limestone and gypsum, but especially because of the interpenetration of some thermophilic species from the south, reaching here their northern limits, with those from the northern areas, mainly from the Carpathians. At the same time, some Pannonian elements penetrate into the Silvanian Hills and some continental steppic species arrived here from the Transylvanian Basin.

Furthermore, we have discovered a number of new populations of rare species in Romania, even new species for the Romanian flora. Therefore, the conservation and protection of these species is even more necessary, especially since the human activities in the region have intensified.

These nine areas proposed for conservation can be considered the most diverse floristic regions in the county. In the future, we want to continue our research on these sites and on others with a high number of species and habitats.

Acknowledgments: The studies were conducted with the support of Prof. Gavril Ardelean from the Western University of "Vasile Goldiș" and the leadership of the Biological Research Centre, Jibou, who provided the necessary means of transport and accommodation. 


\section{REFERENCES}

1. Anonymous, 1975, Anexa I La Decizia 259/29. VII, 1975, Lista rezervaţiilor naturale, locurilor fosilifere, arboretelor, speciilor rare de plante şi animale, existente pe teritoriul judeţului care se impun a fi ocrotite, Mediul ecologic şi educaţia contemporană, Zalău, 1979, pp. 188-189.

2. Anonymous, 2000, Lege privind aprobarea Planului de amenajare a teritoriului naţional - Secţiunea a III-a zone protejate. I. Zone naturale protejate de interes naţional şi monumente ale naturii, Monitorul Oficial al României. Partea I. Legi, Decrete, Hotărâri şi alte acte. Anul XII, nr. 152, miercuri 12 aprilie 2000, pp. 1-22.

3. Anonymous, 2006, Raportul privind starea factorilor de mediu în regiunea 6 NV, în anul 2006, elaborat de Agenţia Regională pentru Protecţia Mediului Cluj.

4. Anonymous, 2015, The Euro-MedPlantbase Project. Dahlem, Berlin (accessed 20 November 2017), http://ww2.bgbm.org/EuroPlusMed/query.asp.

5. Abrudan, I., Medve, A., 2008, Ghidul ariilor naturale protejate din judeţul Sălaj, Zalău, Editura „Şcoala Noastră", 215 pp.

6. Boșcaiu, N., Coldea, G., Horeanu, C., 1994, Lista Roşie a plantelor vasculare dispărute, periclitate, vulnerabile şi rare din flora României, Ocrot. Nat., 38 (1): 45-56.

7. Ciocârlan, V., 2009, Flora ilustrată a României - Pteridophyta et Spermatophyta. /Ediţia a III-a/. Bucureşti, Editura Ceres, $1141 \mathrm{pp}$.

8. Dihoru, G., Dihoru, A., 1994, Plante rare, periclitate şi endemice în Flora României - Lista roşie • Red list of rare, threatened and endemic plants from Flora of Romania, Acta Bot. Horti Bucurest., 173-197.

9. Dihoru, G., Negrean, G., 2009, Cartea roşie a plantelor vasculare din România, Editura Academiei Române. Bucureşti, 1-630.

10. Feichtinger, S., 1875, Krasznamegye és környéke Flórájáról • Flora des Comitates Kraszna und Umgebung, Math. Termtud. Közl., 1871, 9 (3): 55-115.

11. Gafta, D., Mountford, J.O., 2008, Manual de interpretare a habitatelor Natura 2000 din România, Editura Risoprint, Cluj-Napoca.

12. Medve, M., 1990, Valorificarea florei spontane din Culmea Prisnelului, Lucrare metodico-ştiinţifică pentru obţinerea gradului didactic I. Universitatea din Cluj-Napoca, Facultatea de Biologie, Geografie şi Geologie, Catedra de Botanică.

13. Munteanu, D., Raus, D.M., 1984, Documentaţii pentru crearea unor rezervaţii naturale de interes naţional în judeţul Sălaj • Documentation concerning the creation of some natural reservations of national interest in the Sălaj district, Acta Mvsei porolissensis (Zalău), 8: 571-584.

14. Negrean, G., 2001, Lista roşie a plantelor din România existente în pajişti (inclusiv endemite şi subendemite). Pp. 30-58. In: Coldea, G., Negrean, G., Sârbu, I., Sârbu, A., 2001, Ghid pentru identificarea şi inventarierea pajiştilor seminaturale din România. Editura alo, Bucureşti, 58 pp.

15. Negrean, G., Oltean, M., 1989, Endemite şi zone endemoconservatoare din Carpaţii Sud-Estici • Endemites and endemoconservation areas in the South-Eastern Carpathians, Ocrot. Nat., 33 (1): 15-25.

16. Oltean, M., Negrean, G., Popescu, A., Roman, N., Dihoru, G., Sanda, V., Mihăilescu, S., 1994, Lista roşie a plantelor superioare din România. In: Oltean, M. (coord.), Studii, sinteze, documentaţii de ecologie, Acad. Română, Institutul de Biologie, 1: 1-52.

17. Raus, D.M., 1984, Studii floristice asupra mlaştinei de la "Băile Iaz" • Études floristique sur la marécage de "Băile Iaz”, Acta Mvsei porolissensis (Zalău), 8: 585-590.

18. Roskov, Y., Abucay, L., Orrell, T., Nicolson, D., Bailly, N., Kirk, P.M., Bourgoin, T., DeWalt, R.E., Decock, W., De Wever, A., Nieukerken, E. van, Zarucchi, J., Penev, L., eds. (2017). Species 2000 \& ITIS Catalogue of Life, 28th November 2017. Digital resource at www.catalogueoflife.org/col. Species 2000: Naturalis, Leiden, the Netherlands. ISSN 2405-8858.

19. Săvulescu, T., (ed.). 1952-1976, Flora României • Flora Romaniae. Editura Academiei Române, Vol. 1-13, Bucureşti.

20. Sârbu, I., Ștefan, N., Oprea, A., 2013, Plante vasculare din România, Editura VictorBVictor, Bucureşti.

21. Szabó, A.T., 1983, Vegetaţia gipsofilă din sud-vestul Podişului Someşan • Gypsophilous plant communities from the south-west of the Someş plateau, Ocrot. Nat., 27 (2): 103-111.

22. Szatmari, P.-M., Căprar, M., 2015, Research on spontaneous and subspontaneous flora of Botanical Garden „Vasile Fati” Jibou, Journal of Horticulture, Forestry and Biotechnology, 19 (2): 176-189. 
23. Szatmari, P.-M., 2016, Ophrys apifera (Orchidaceae) in Transylvanian flora, Romania, Acta Horti Botanici Bucurestiensis, 43: 31-40.

24. *** The Plant List, 2013, Version 1.1. Published on the Internet; http://www.theplantlist.org/ (accessed 20 November 2017).

25. *** OUG 57/2007. Ordonanţa de urgenţă $\mathrm{nr} .57$ din 20 iunie 2007 privind regimul ariilor naturale protejate, conservarea habitatelor naturale, a florei şi faunei sălbatice. Guvernul României (Natura 2000 Romanian law).

\section{ARII CU DIVERSITATE FLORISTICĂ RIDICATĂ DIN JUDEṬUL SĂLAJ CE NECESITĂ PROTECT⿱IE ȘI CONSERVARE}

\section{(Rezumat)}

În urma studiilor floristice întreprinse pe parcursul mai multor ani pe întreg cuprinsul județului Sălaj s-au identificat mai multe regiuni cu o diversitate floristică excepțională. Habitatele din zonele respective sunt în marea lor majoritate puțin afectate de activitatea umană, dezvăluind o imagine de ansamblu asupra vegetației de odinioară a județului. Ele conțin o serie de specii rare, protejate, endemice, relicte de stepă sau specii interesante din punct de vedere științific și floristic. Printre acestea se numără zone de mlaștină, păduri, stâncării calcaroase, gipsuri și pajiști caracteristice stepelor transilvănene.

Înființarea unor rezervații care să cuprindă aceste areale de vegetaţie este aşadar deosebit de importantă pentru asigurarea perpetuării acestor specii rare, unele dintre ele având populații însemnate. Multe dintre aceste specii ating limita nordică în România sau sunt semnalate pentru prima dată din regiunea de nord-vest a țării. Aceste propuneri de rezervații vin ca urmare a unor cercetări detaliate ale zonelor respective, studii care ajută la o mai bună cunoaștere a florei Sălajului, mai puțin documentată în ultimele decenii, din care cauză județul are un număr foarte mic de arii protejate. 